\title{
Effects of high fat diet on kidney lipid content and the $\mathrm{Na}$,K-ATPase activity
}

\author{
Israel José Pereira Garcia ${ }^{1}$, Jessica Silva Cézar ${ }^{1}$, Bruno Silva Lemos ${ }^{2}$, Lilian Nayra Silva ${ }^{2}$, Rosy Iara \\ Maciel de Azambuja Ribeiro ${ }^{3}$, Camilla Camerino Santana ${ }^{4}$, Luciano Aparecido Meireles Grillo ${ }^{4}$, \\ Flavia Carmo Horta Pinto ${ }^{5}$, Samyra Lopes Buzelle ${ }^{6}$, Vanessa Faria Cortes ${ }^{1}$, Hérica de Lima Santos ${ }^{1}$, \\ Maria Emilia Soares Martins dos Santos ${ }^{2,7}$, Leandro Augusto Barbosa ${ }^{1^{*}}$
}

\begin{abstract}
${ }^{1}$ Laboratório de Bioquímica Celular, Faculdade de Bioquímica, Universidade Federal de São João Del Rei, Campus Centro-Oeste Dona Lindu, Divinópolis, Minas Gerais, Brasil, ${ }^{2}$ Laboratório de Bioquímica Metabólica, Faculdade de Bioquímica, Universidade Federal de São Joao Del Rei, Campus Centro-Oeste Dona Lindu, Divinópolis, Minas Gerais, Brasil, ${ }^{3}$ Laboratorio de Patologia Experimental, Universidade Federal de São João Del Rei, Campus Centro-Oeste Dona Lindu, Divinópolis, Minas Gerais, Brasil, ${ }^{4}$ Universidade Federal de Alagoas, Escola de Enfermagem e Farmácia, Campus A C Simões, Maceió, Alagoas, Brasil, ${ }^{5}$ Departamento de Ciências Naturais (DCNA), Universidade Federal de São João Del Rei, Campus Dom Bosco, São João Del Rei, Minas Gerais, Brasil, ${ }^{6}$ Departamento de Bioquímica, Faculdade de Medicina de Ribeirão Preto, Universidade de São Paulo, Ribeirão Preto, São Paulo, Brasil, ${ }^{7}$ Departamento de Bioquímica, Farmacologia e Fisiologia/ICBN, Universidade Federal do Triângulo Mineiro, Uberaba, MG, Brasil
\end{abstract}

\begin{abstract}
It is widely known that high fat diet (HFD) can contribute to the advent of health problems. Recent studies have indicated that obesity imposes a hemodynamic overload to the kidneys. In order to further investigate such injuries, two groups of six Swiss mice each were fed with a controlled AIN93G diet or a high fat (AIN93G modified) diet for eight weeks. Blood samples were collected to determine the hormonal, lipid profile, glucose, urea, and creatinine levels. Histopathological and immunohistochemical analysis were carried out to analysis the kidney damage. Fractions of renal membranes were prepared to assess the Na,K-ATPase activity, lipid peroxidation, total cholesterol, and phospholipid content. The results indicated that the blood lipid profile, urea and creatinine was not altered by the HFD. On the other hand, it was observed in HFD diet mice elevated glucose blood levels along with an augment on insulin and a decrease on corticosterone release. HFD provoked a reduction in the diameter of the convoluted tubules and cell volume in Bowman's capsule and an increased number of positive cells with Na,KATPase, but reduced the Na,K-ATPase activity and the cholesterol content in the kidney cell membrane but favored the lipid peroxidation.
\end{abstract}

Keywords: High fat diet/Effects. Na,K-ATPase. Lipid peroxidation. Kidney. Cell membrane.

\section{INTRODUCTION}

The profound scientific, technological and socioeconomic changes observed throughout the history of the societies promoted a striking impact on their demographic, nutritional and epidemiological profiles. Modifications on the dietary patterns with the introduction of hypercaloric and high fat diets (HFD)

\footnotetext{
*Correspondence: L. A. Barbosa. Universidade Federal de São João Del Rei, Campus Centro-Oeste Dona Lindu. Av Sebastião Gonçalves Coelho, 400, CEP 35501-296 Divinopolis, MG, Brasil. Email: leaugust@yahoo.com.br. Phone: 55-37-3221-1610
}

contributed to elevate the incidence of overweight and obesity worldwide. As consequence, a transformation on health-disease process could be observed specifically with the augment of the prevalence of chronic diseases such as diabetes, hypertension, cardiovascular impairment, and cancer (Crescenzo et al., 2015; Frazier-Wood, 2015; McKeown, 2009).

Pre-clinical studies have shown a direct correlation between a high fat diet and the overweight/obesity among distinct animal models (Dalboge et al., 2015; Lee et al., 2014). An important aspect not often discussed in such studies, is the relationship between the overweight and obesity caused by hypercaloric and high fat diet and the 
development of kidney failure. In fact, a retrospective study revealed a prevalence of $70 \%$ of metabolic syndrome among 202 patients with kidney failure admitted to initiate the renal replacement therapy (Young et al., 2007).

A review involving 6,618 renal biopsies performed from 1986 to 2000 , reported a ten-fold increase in the incidence of obesity-associated glomerulonephritis in 2000 when compared to those investigated in 1986 (Kambham et al., 2001). Obesity imposes a hemodynamic burden to the kidneys, which is characterized by glomerular hyperfiltration and microalbuminuria. It was observed that dogs with obesity induced by high fat diet presented an elevation of $30 \%$ on the glomerular filtration rate five weeks after the induction, along with an expansion of Bowman's capsule and an augment of mesangial matrix after nine weeks (Henegar et al., 2001). In addition, it has been described that changes in lipoprotein metabolism and serum lipids occur with increasing renal dysfunction. A subgroup analysis of 1,329 CKD (Chronic kidney disease) patients followed over 5 years, showed a relative risk reduction of $28 \%$ with sinvastatin treatment. (Chauhan, Vaid, 2009; Choudhury, Tuncel, Levi, 2009; Szolkiewicz et al., 2002). Moreover, the high levels of cholesterol and obesity have been associated with changes of glomerular structure during the final stages of renal disease (Sasatomi et al., 2001).

$\mathrm{Na}, \mathrm{K}-\mathrm{ATP}$ ase exerts pivotal physiological functions in the kidneys, such as a primary role in the reabsorption of $\mathrm{Na}^{+}$and water, which is essential for the maintenance of body fluid and electrolyte homeostasis (Reinhard et $a l ., 2013)$. Moreover, the lipid content on the plasma membrane of the cells can modulate the activity and functions modulates by the Na,K-ATPase (Cornelius, 2008; Yoneda et al., 2014). Since HFD is capable of impair the kidney functions and also cause modulations of lipid content in the body, it is important to verify the effect of HFD on the activity of the Na,K-ATPase, an important enzyme responsible for several kidney functions.

Furthermore, there is a few reports about the influence of HFD on the kidney Na,K-ATPase activity. High fat diets induces an interaction between $\mathrm{Na}, \mathrm{K}-$ ATPase and CD36, a receptor that plays an important role in the metabolism of fatty acids and glucose (Kennedy et al., 2013). According to this particular study, the products generated in a hyperlipidemia state, activate CD36 and $\mathrm{Na}, \mathrm{K}-\mathrm{ATP}$ ase, both being involved in the activation of Src kinases and the generation of free radicals. The authors suggested that CD36 and $\mathrm{Na}, \mathrm{K}-\mathrm{ATP}$ ase acts synergically, developing an inflammatory cycle in the renal proximal tubule cells including the associated macrophages. In obese rats, leptin provoked urine output by only $29.1 \%$ and natriuresis by $28.9 \%$, and had no significant effect on medullary Na,K-ATPase, but the obese rats had an increased of Na,K-ATPase activity compared to lean rats (about 40\%) (Beltowski, Gorny, Marciniak, 2002).

Therefore, the objective of the present study was to assess the effect of a high fat diet on the Na,K-ATPase activity of Swiss male mice fed. Changes in body weight, adipose tissue depots, serum levels of metabolic markers, and renal function markers were investigated. Additionally, histopathological and immunohistochemical analysis were carried out to analysis the kidney damage and fractions of renal membranes were prepared to assess the $\mathrm{Na}, \mathrm{K}$-ATPase activity, lipid peroxidation, total cholesterol, and phospholipid.

\section{MATERIAL AND METHODS}

\section{Sample}

Male 4-week-old Swiss mice, receiving a commercial diet were housed in number of six in cages in an environmentally controlled room (light from 6 AM to $6 \mathrm{PM}$; mean temperature, $22 \pm 1{ }^{\circ} \mathrm{C}$ ) at the animal facility of the Midwest Campus of the São João del-Rei Federal University. After the acclimatizing period (3 days), the animals were randomly divided into 2 groups of 12 animals with free access of food and water. The control (CT) group was fed with a standard balanced diet (AIN93G) composed of $7 \%$ lipid, $63 \%$ carbohydrate and $20 \%$ protein, while the HFD group was fed with a fat diet (modified AIN93G) composed of $35 \%$ lipid, $35 \%$ carbohydrate and $20 \%$ protein (Table I) for 8 weeks. After this period, blood, retroperitoneal and edipidymal adipose tissue and kidneys were collected in order to perform the experiments. The animals were managed according to the Brazilian College of Animal Experimentation Rules and approved by the Animal Ethics Committee - Commission for the Ethical Use of Animals at the Federal University of São João delRei (CEUA-UFSJ) - under the Protocol Number 11/2012.

\section{Preparation of kidney crude membrane homogenates}

The kidneys of each animal were removed. Each kidney was individually crushed, placed in a $10 \mathrm{mM}$ Tris-HCl buffer solution ( $\mathrm{pH}$ 7.4) and homogenized. The crude homogenate was centrifuged at 9,000 $\mathrm{g}$ for 60 minutes, at $4{ }^{\circ} \mathrm{C}$. The pellets were resuspended to obtain renal membrane homogenates from right and left kidneys, respectively. The aliquots were immediately frozen and stored at $-80^{\circ} \mathrm{C}$. 
TABLE I - Composition of control diet and High fat diet

\begin{tabular}{lcc}
\hline Ingredients & $\begin{array}{c}\text { Control Diet } \\
(\mathbf{g} / \mathbf{1 0 0} \mathbf{g})\end{array}$ & $\begin{array}{c}\text { High Fat Diet } \\
(\mathbf{g} / \mathbf{1 0 0} \mathbf{g})\end{array}$ \\
\hline Casein & 20.0 & 20.0 \\
L-Cystine & 0.3 & 0.3 \\
Corn starch & 39.8 & 11.8 \\
Maltodextrin & 13.2 & 13.2 \\
Sucrose & 10.0 & 10.0 \\
Soybean oil & 7.0 & 4.0 \\
Lard & - & 31.0 \\
Cellulose & 5.0 & 5.0 \\
Mineral mix & 3.5 & 3.5 \\
Vitamin mixture & 1.0 & 1.0 \\
Choline bitartrate & 0.25 & 0.25 \\
\hline Total & 100 & 100 \\
\hline
\end{tabular}

\section{Extraction of lipid fractions from the crude membrane homogenates}

Samples of $100 \mu \mathrm{L}$ from the crude membrane homogenates were mixed with 20 volumes of chloroform:methanol $(2: 1 \mathrm{v} / \mathrm{v})$ in Falcon tubes $(15 \mathrm{~mL})$. After $1 \mathrm{~h}$ at room temperature, the tubes were centrifuged at 2,100 $\mathrm{rpm}$ for $20 \mathrm{~min}$. A volume of distilled water corresponding to $1 / 5$ of total volume $(\sim 400 \mu \mathrm{L})$ was added to each tube which was settled for $1 \mathrm{~h}$ at room temperature before new centrifugation cycle as previous described. After $24 \mathrm{~h}$, the organic phase (mainly containing phospholipids and cholesterol) was retrieved, dried on a rotary evaporator, dissolved in chloroform:methanol $(2: 1 \mathrm{v} / \mathrm{v})$, and subsequently stored at $-20^{\circ} \mathrm{C}$ (Folch, Lees, Stanley, 1957).

\section{Determination of total phospholipids from the crude membrane homogenates}

The phospholipids were determined based on the amount of phosphate released by the acid hydrolysis (Chen, Toribara, Warner, 1956). Previously known amounts of Pi (5 to $80 \mathrm{nmol}$ ) and samples of commercial dioleoylphosphatidylcholine (DOPC) were used to assess the lipid hydrolysis and to prepare the standards.

\section{Determination of total cholesterol from the crude membrane homogenates}

To quantify the cholesterol, $1.5 \mathrm{~mL}$ of acetic acid and $1 \mathrm{~mL}$ of ferric chloride reagent $\left(2.5 \% \mathrm{w} / \mathrm{v} \mathrm{FeCl}_{3}\right.$ in $85 \%$ w/v $\mathrm{H}_{3} \mathrm{PO}_{4}$ diluted in concentrated $\mathrm{H}_{2} \mathrm{SO}_{4}, 8 \% \mathrm{v} / \mathrm{v}$ ) were added to each sample. The absorbance of a purple/pink color developed after $20 \mathrm{~min}$ was read in a plate reader set at $550 \mathrm{~nm}$. A standard curve was prepared simultaneously (Rackova, 2013).

\section{Determination of Thiobarbituric Acid Reactive Substances (TBARS)}

Lipoperoxidation was determined by the quantification of TBARS levels. In a $100 \mu \mathrm{L}$ aliquot of mice membrane kidney crude membrane homogenate the volume was filled to $200 \mu \mathrm{L}$ with $50 \mathrm{mM}$ sodium phosphate buffer (pH 7.4). A $200 \mu \mathrm{L}$ of $12 \%$ trichloroacetic acid (TCA) was added and then $400 \mu \mathrm{L}$ of $1 \%$ thiobarbituric acid was added. The mixture was vortexed and taken to the water bath at $95{ }^{\circ} \mathrm{C}$ for 30 minutes. After this period, it was taken to the ice bath for 10 minutes. After this time, the absorbance was read in a spectrophotometer at 532 $\mathrm{nm}$ (Buege, Aust, 1978). The determinations were made in triplicate, and the quantification of the lipoperoxidation was calculated with respect to a standard curve. The standard curve was taken from a standard solution of malondialdehyde (MDA) by varying the amount of 0 to $300 \mathrm{nM}$.

\section{Metabolism and biochemical measurements}

The animals were sacrificed by decapitation between 8 and 10 o'clock in the morning. Blood samples were collected and the serum used for biochemical analyses. Serum free fatty acid (FFA) (NEFA Randox ${ }^{\circledR}$ ), triacylglycerol (TAG) $\left(\right.$ Labtest $\left.^{\circledR}\right)$, cholesterol $\left(\right.$ Doles $\left.^{\circledR}\right)$, urea, creatinine and glucerol (Bioclin-Quibasa $\left.{ }^{\circledR}\right)$, were all determined enzymatically by commercial kits. The glucose was determined by using a glucometer (Accu-Chek Performa; Roche ${ }^{\circledR}$ ). ELISA was used for determination of serum concentrations of adiponectin (R\&D System Inc. ${ }^{\circledR}$ ), leptin, and insulin $\left(\right.$ Millipore $\left.^{\circledR}\right)$. The corticosterone serum concentrations were measured by radioimmunoassay.

\section{$\mathrm{Na}, \mathrm{K}$-ATPase activity}

The Na,K-ATPase activity was evaluated using 20 $\mu \mathrm{g}$ of the total membrane homogenates per $\mathrm{ml}$ of reaction medium ( $\mathrm{pH} 7.5$ ) consisted of $50 \mathrm{mM}$ HEPES, $3 \mathrm{mM}$ ATP, $10 \mathrm{mM} \mathrm{KCl}, 5 \mathrm{mM} \mathrm{MgCl}$, and $50 \mathrm{mM} \mathrm{NaCl}$. The reaction was conducted at $37^{\circ} \mathrm{C}$. The experiments were performed in the presence and the absence of $1 \mathrm{mM}$ ouabain, in order to specifically determine the activity of $\mathrm{Na}, \mathrm{K}-\mathrm{ATP}$ ase. The reaction started by the addition of the 
enzyme to the reaction medium and was interrupted by the addition of cold $30 \%$ TCA after 1 hour. The tubes were placed in an ice bath in order to reduce the ATP hydrolysis and centrifuged $2000 \mathrm{rpm}$ for 10 minutes. The phosphate was then determined following the method described by Heinomen and Lahti (1981).

The Na,K-ATPase activity was calculated by the difference between the two assays regarding the total of ATPase (without or without ouabain). The enzyme activity was expressed as nmol/min/mg protein.

\section{Histochemistry}

The fragments of renal tissue were fixed in $10 \%$ of buffered formaldehyde and dehydrated by increased alcohol concentrations ( 70 to $100 \%$ ). The fragments were cleaned three times in xylene baths before be embedded in paraffin. Sections of $4 \mu \mathrm{m}$ thick were fixed on glass slides. For histochemical analysis the slides were rehydrated in with decreasing concentrations (100 to $70 \%$ ) of alcohol and afterwards in tap water. The slides were then submitted to hematoxylin, and next, to eosine. Images of the histologic fields were obtained by a Zeiss Axiolab microscope connected to a camera interconnected to a board computer scanner (Zeiss, Axiovision Rel. 4.6).

Morphometric analyzes (Sharma et al., 1995) were performed with the help of the Image J program (National Institute of Health, USA). For morphometric analysis of the Bowman space area, 10 glomeruli of each animal of each group were photographed, in an increase of 200X. The area of the glomerular capillary tuft and the Bowman capsule area were measured, the Bowman space area being obtained by subtracting the tuft area with the capsule area. The average of the 10 values of the measured area was considered as the average area for each one of the animals. For morphometric analysis of the inner diameter of the proximal tubules, 30 tubules of each animal of each group were photographed and identified by the classic morphology of their epithelial cells, in an increase of 200X. The mean of the 30 values of the internal diameter measured was considered as the mean diameter for each of the animals.

\section{Immunohistochemistry}

Immunohistochemistry was performed with $4-\mu \mathrm{m}$ sections that were deparaffinized with xylene and then rehydrated in decreasing concentrations of ethanol. Antigen retrieval was performed by incubating the specimens in a sodium citrate buffer (1 M, pH 6.0 to 6.2) using three 5-minutes cycles in a microwave with 1-minute interval between the cycles. The slides were washed twice with $1 \mathrm{M}$ PBS for 5 minutes. The blocking of the endogenous peroxidase was performed with $30 \% \mathrm{H}_{2} \mathrm{O}_{2}$ in a dark humid chamber with three changes of 20 minutes each. The specimens were again rinsed twice with $1 \mathrm{M}$ PBS for 5 minutes. The blocking was achieved with $2 \%$ bovine serum albumin (BSA). After the blocking, there was further wash with PBS (twice for 5 minutes each). The incubation was performed using the polyclonal primary antibody alpha1 Na,K-ATPase (Santa Cruz Biotechnology, C464.6: sc-21712, Santa Cruz, CA, USA) at a dilution of $1: 100$ for 12 hours in a dark humid chamber at $4{ }^{\circ} \mathrm{C}$. After that, the secondary antibodies (HRP-System LBSA - DAKO) were incubated for 45 minutes under the same conditions. The excess of secondary antibodies was removed by washing with $1 \mathrm{M}$ PBS. The specimens were incubated with the horse-radish peroxidase (HRP) enzyme for 45 minutes in a humid chamber followed again by two baths 1 M PBS for 5 minutes. The final products were revealed by the DAB substrate chromogen $3.3(100 \mathrm{mg}$, Sigma, USA), $1.2 \mathrm{~mL}$ of $30 \% \mathrm{H}_{2} \mathrm{O}_{2}$, and $120 \mathrm{~mL}$ of PBS at $37^{\circ} \mathrm{C}$ for 6 minutes. The specimens were then washed in water for 5 minutes, counterstained with hematoxylin for 40 seconds. Finally, the tissues were dehydrated. Negative and positive controls for every immunohistochemical staining process were used to ensure the quality of the staining. Two independent observers evaluated the extent of the expression of each of the markers on a $40 x$ field.

\section{Statistical analysis}

GraphPad Prism ${ }^{\circledR} 5$ package was applied to compare the means of the continuous variables using the unpaired Student's t test. 5.0\% $\alpha$ was established for the significant analysis.

\section{RESULTS}

\section{Body weight and adipose tissue depots}

The HFD mice showed increased body weight when compared to control mice. This was observed from second week, until the end of the experimental period (Figure 1). After 8 weeks, the HFD mice also presented an augment of $169 \%$ in their adipose tissue depots (retroperitoneal (RET) and $107 \%$ of epididymal (EPD) tissues) when compared to control group (Table II).

\section{Histopathological analysis of the kidneys}

Control diet did not alter the integrity of the capsules, renal corpuscles and convoluted proximal 


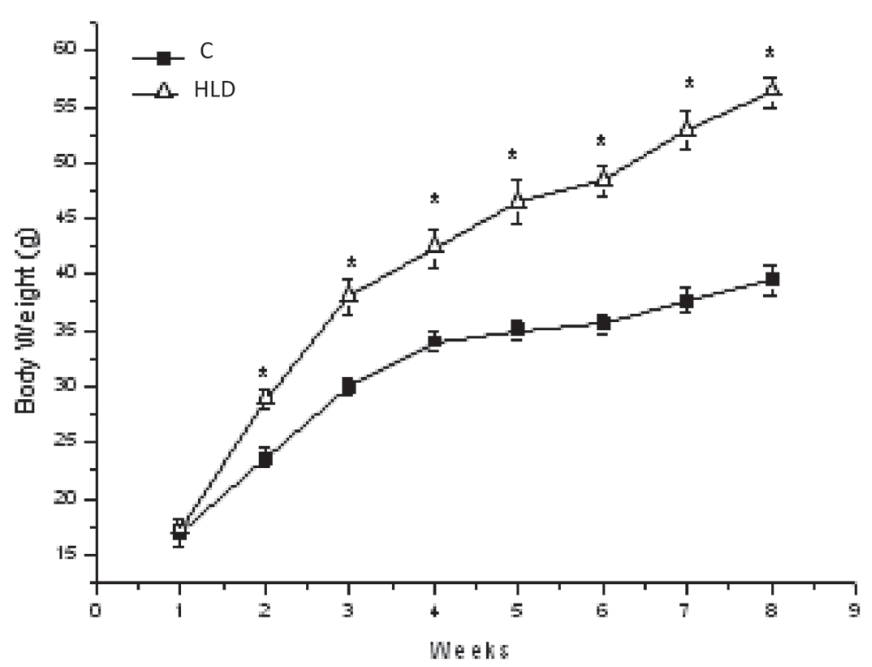

FIGURE 1 - Body weight of mice fed a controle diet (C) or a high fat diet (HFD) for 8 weeks. Results are mean \pm standard error $(\mathrm{n}=6)$. ${ }^{*}$ versus $\mathrm{C}(\mathrm{P}<0.05)$.

TABLE II - Adipose tissue depots (g) (retroperitoneal (RET) and epididimal (EPD) of mice fed with a control diet (C) or a high fat diet (HFD) for 8 weeks. Results are mean \pm standard error $(n=6)$. *versus $C(p<0,05)$

\begin{tabular}{lcc}
\hline Groups & RET & EPD \\
\hline C & $0.286 \pm 0.05$ & $1.4 \pm 0.2$ \\
HL & $0.770 \pm 0.06^{*}$ & $2.9 \pm 0.3^{*}$ \\
\hline
\end{tabular}
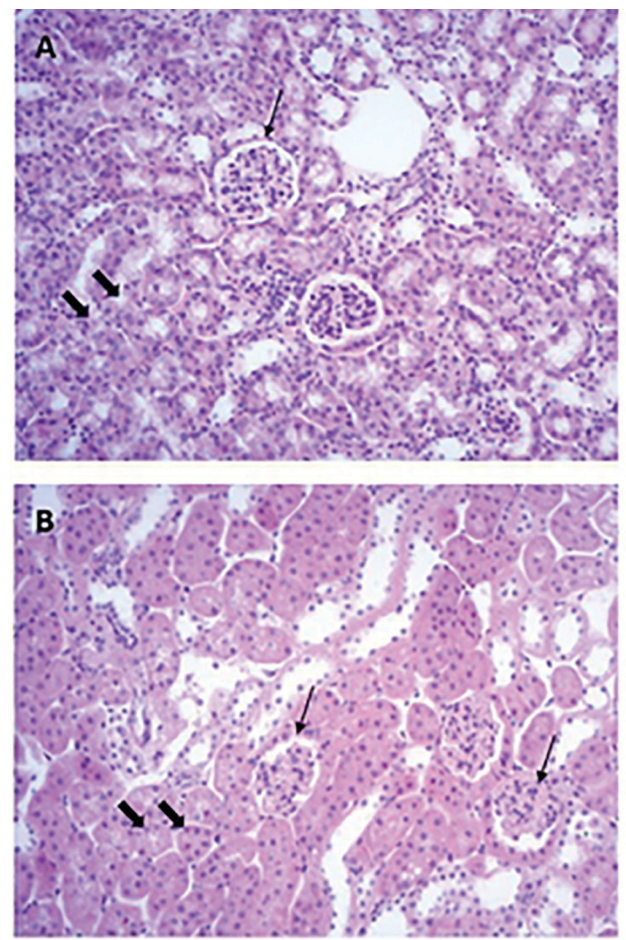

tubules at kidney sections observed by microscopic analyses, (Figure 2A). In a different manner, for the HFD group it was possible to observe areas with a swelling in the cells lined (Figure 2) with the convoluted proximal tubules leading to a reduction of their internal diameters and a decrease of cell volume in Bowman's capsule, as shown in Figure 3.

\section{Biochemical analysis of metabolism}

Blood levels of urea, creatinine, lipid profiles, adiponectin, and leptin levels were not different between both groups. However, it was observed an increase of glucose $(\mathrm{p}<0.001)$ and insulin $(\mathrm{p}<0.032)$, and a decrease of corticosterone levels $(p<0.001)$ in HFD group compared to the control (Table III).

\section{$\mathrm{Na}, \mathrm{K}$-ATPase activity}

$\mathrm{Na}, \mathrm{K}$-ATPase activity of the HFD group showed a reduction of $25 \%$ and $37 \%$ for right and left kidney, respectively (Figure 4). Interestingly, it was noticed a higher $\mathrm{Na}, \mathrm{K}$-ATPase activity, of about 4 times greater, in the right kidney compared to the left kidney. However, it is worth of note that the effect of HFD diet remains the same in both the kidneys indicating a modulation of the renal function.
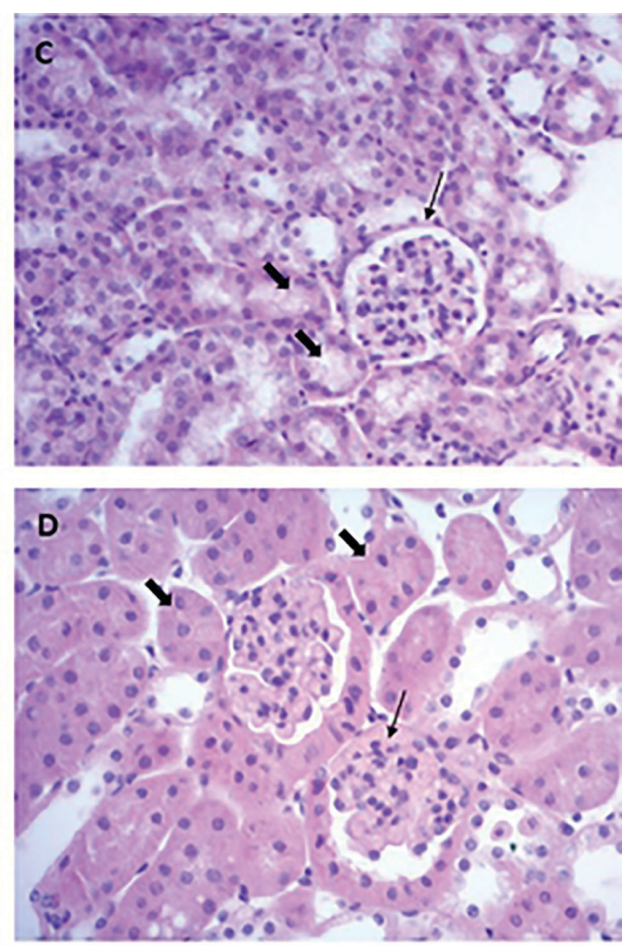

FIGURE 2 - Photomicrography of kidney transversal section, stained with HE (A,B: 200X; C,D 400X). The thin arrows correspond to the renal corpuscle and the thick arrows indicate the convoluted tubules. A and C, Control group and B and D, group under HFD. 
A

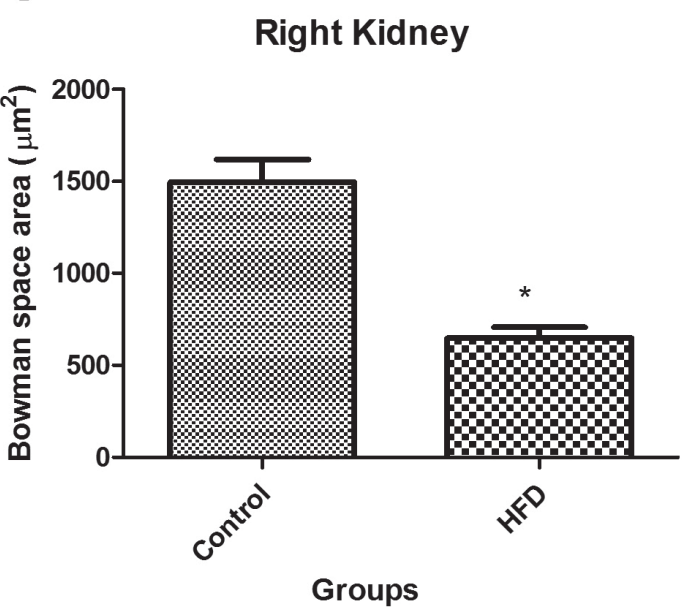

C

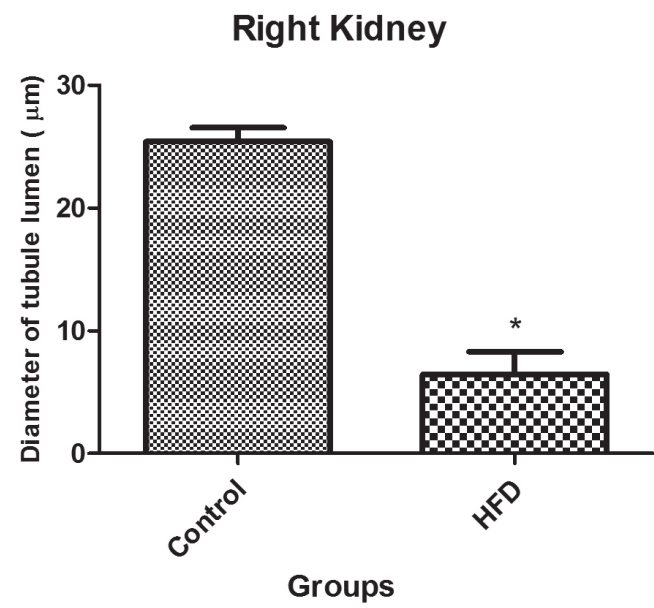

B

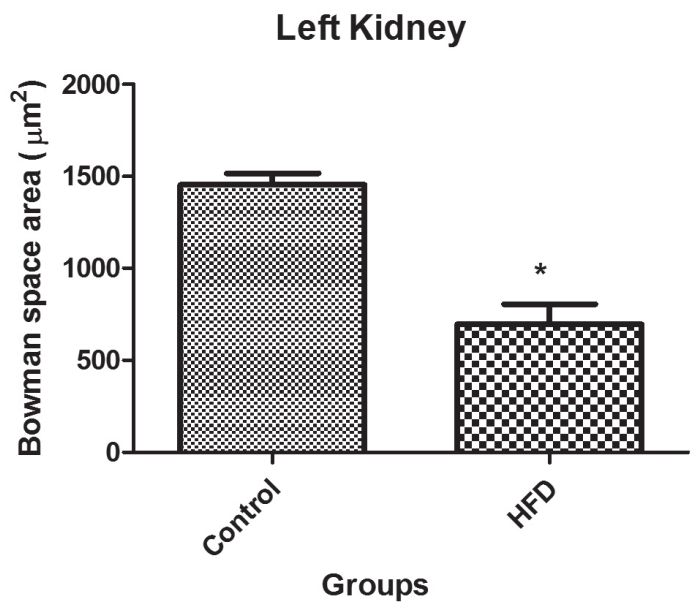

D

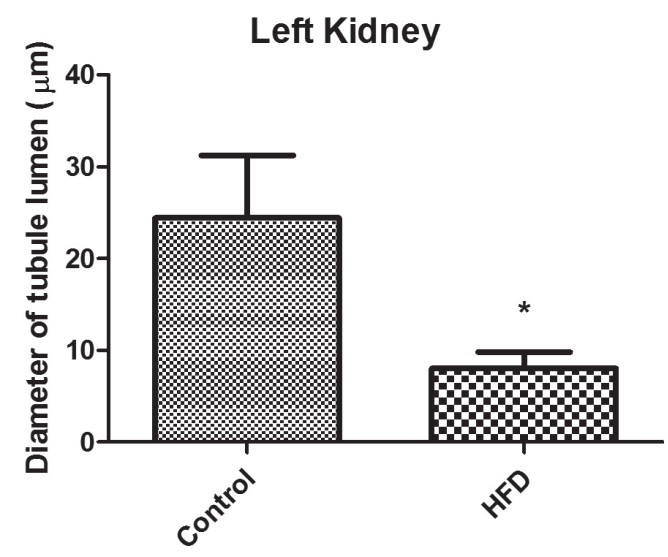

Groups

FIGURE 3 - Morphometric renal analyzes. The Bowman space area (A) and the diameter of tubule lumen (B) was measured. * represent $\mathrm{p}<0.05$ of $t$ test $(\mathrm{n}=6)$.

TABLE III - Biochemical serum/plasma analysis of mice fed control or high-fat diet

\begin{tabular}{lcc}
\hline & Control diet & High-fat diet \\
\hline Adiponectin $(\mu \mathrm{g} / \mathrm{mL})$ & $2.54 \pm 0.13$ & $2.29 \pm 0.19$ \\
Corticosterone $(\mu \mathrm{g} / \mathrm{mL})$ & $1.01 \pm 0.06$ & $0.57 \pm 0.03(\mathrm{p}<0.001)$ \\
Cholesterol $(\mathrm{mg} / \mathrm{mL})$ & $1.03 \pm 0.08$ & $0.99 \pm 0.08$ \\
Free fatty acid $(\mu \mathrm{mol} / \mathrm{mL})$ & $0.66 \pm 0.04$ & $0.68 \pm 0.05$ \\
Glucose $(\mathrm{mg} / \mathrm{dL})$ & $172.1 \pm 8.62$ & $258.2 \pm 17.6(\mathrm{p}<0.001)$ \\
Glycerol $(\mu \mathrm{mol} / \mathrm{mL})$ & $0.12 \pm 0.01$ & $0.17 \pm 0.02$ \\
Insulin $(\mathrm{mUI} / \mathrm{mL})$ & $33.28 \pm 4.22$ & $183.88 \pm 60.43(\mathrm{p}<0.032)$ \\
Leptin $(\mathrm{ng} / \mathrm{mL})$ & $30.20 \pm 0.44$ & $28.68 \pm 1.88$ \\
Triacylglycerol $(\mathrm{mg} / \mathrm{mL})$ & $1.61 \pm 0.12$ & $1.97 \pm 0.24$ \\
Urea $(\mathrm{mg} / \mathrm{dL})$ & $48.98 \pm 7.87$ & $54.20 \pm 4.21$ \\
Creatinin $(\mathrm{mg} / \mathrm{dL})$ & $0.347 \pm 0.06$ & $0.991 \pm 0.30$ \\
\hline
\end{tabular}


The immunohistochemistry study revealed greater labeling profiles of $\mathrm{Na}, \mathrm{K}$-ATPase in the mice that had been treated with the HFD diet than those of control group (Figure 5). This data showed that a HFD diet could increase the number of $\mathrm{Na}, \mathrm{K}$-ATPase positive cells (Figure $5 \mathrm{G}$ ), as well the total Na,K-ATPase stain intensity (Figure $5 \mathrm{H})$ of in the renal tissues.

A

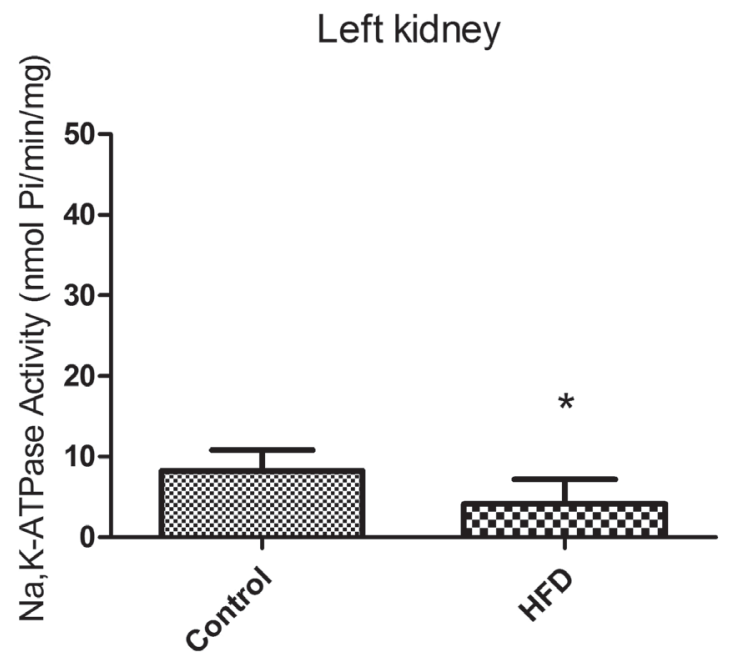

B

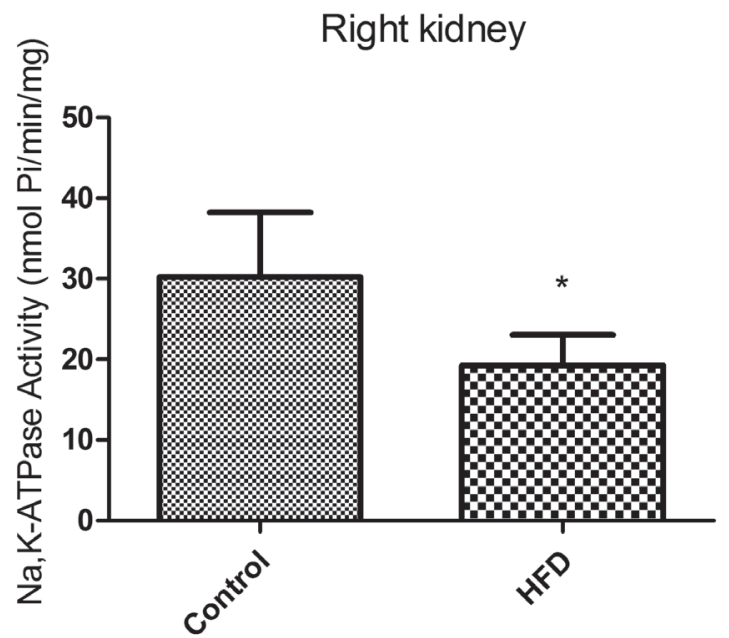

FIGURE 4 - Kidney Na,K-ATPase activity of mice fed with high fat diet. Membrane preparations of left (A) and right (B) kidney were used to determine $\mathrm{Na}, \mathrm{K}$-ATPase activity. The experiments were performed in triplicate. * represent $\mathrm{p}<0.05$ of $t$ test $(\mathrm{n}=6)$.

\section{Cell membrane cholesterol and phospholipid content}

The amount of phospholipids was not altered by HFD fed, but a lower total cholesterol content was observed in kidney membranes fraction, with a reduction of $41 \%$ for the left kidney $(\mathrm{p}<0.05)$ and $25 \%$ for the right kidney $(\mathrm{p}<0.0127)$ (Figure 6).

\section{Lipid peroxidation}

The right kidneys of the mice treated with the HFD presented an augment of $45 \%(\mathrm{p}<0.05)$ in cell membrane lipid peroxidation (Figure 7) when compared to the control group.

\section{DISCUSSION}

HFD fed mice have increased body weight of $52 \%$ after 8 weeks of diet and white adipose tissue depots about $169 \%$ in their adipose tissue depots (retroperitoneal). The use of a high fat diet in order to induce obesity in mice models is a very useful tool to understand the disruptions in the body's metabolism. Overweight and obesity are important causes for several associated pathologies, including hypertension. The pathogenesis of obesityassociated hypertension is very complex, and it is not fully understood. However, as in other forms of hypertension, abnormal renal sodium handling and a disturbed regulation of the vascular tone, plays predominant roles (Seki et al., 2008).

Increased WAT depots are expected in high fat fed animals. In our study, HFD dietary intake for 8 weeks did not cause changes in the plasma lipid profile of the animals: concentrations of FFA, TAG and cholesterol were not different, which may indicate that peripheral tissues, mainly liver and white adipose tissue (WAT) are able to capture dietary FFA in an attempt to avoid ectopic deposition. Fatty acid esterification into TAG in WAT seems to protect organisms from FFA lipotoxicity to other organs, once derived FFA from WAT can impair peripheral tissues function, resulting insulin resistance and hepatic steatosis (Cao et al., 2008). Kwon et al. studied the temporal effect of HFD in C57BL / 6J mice observed results similar to ours, with no differences in plasma levels of TAG and FFA up to 24 weeks of diet (Kwon et al., 2012).

Despite the fact that mutations resulting in the absence of leptin or its receptor have been associated with severe obesity and diabetes, diet-induced obesity in animals and humans has been characterized by hyperleptinemia (Surwit et al., 1997). After 4 and 14 wk, plasma leptin concentrations are lower in rats fed the HFD. In the short term, a moderately HFD is associated with lower than expected circulating leptin concentrations, which correlate with a higher body weight. And authors argue that a HFD may therefore contribute to weight gain 

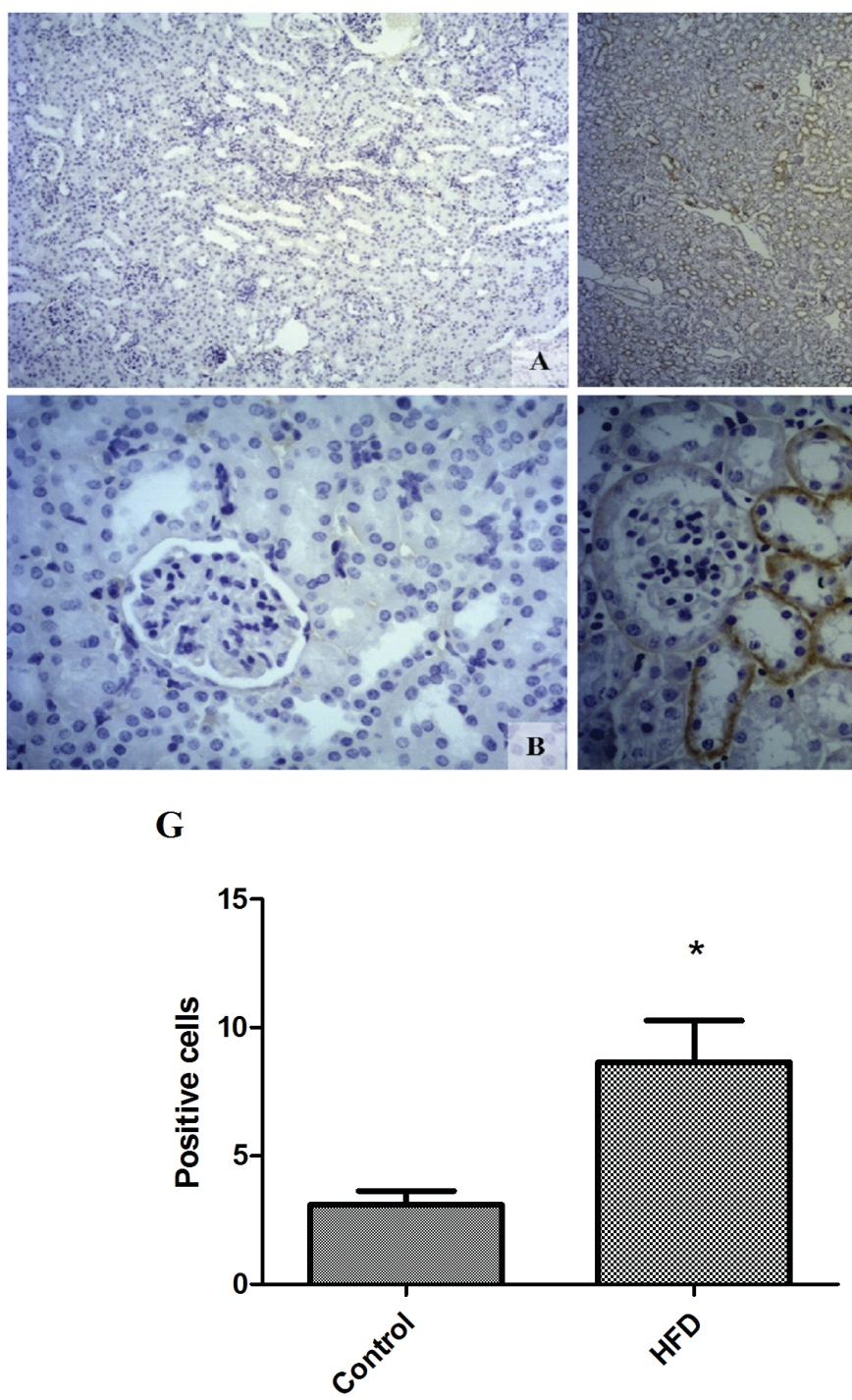

G
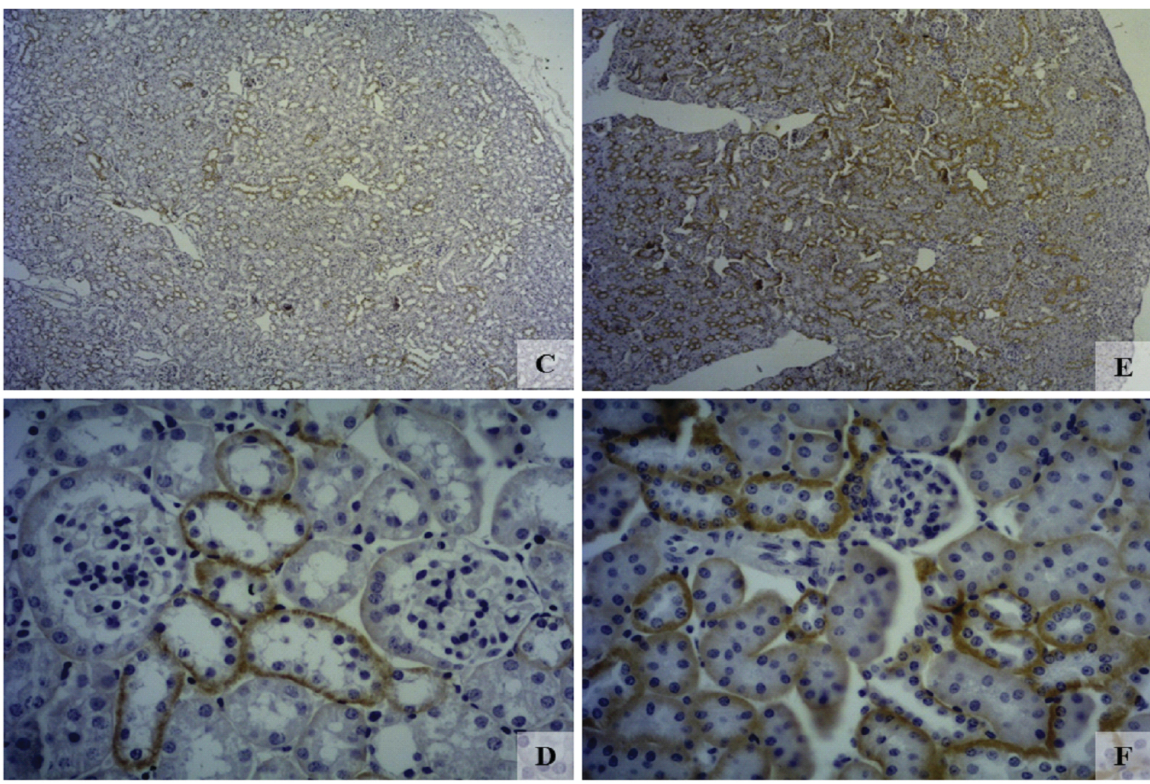

$\mathbf{H}$

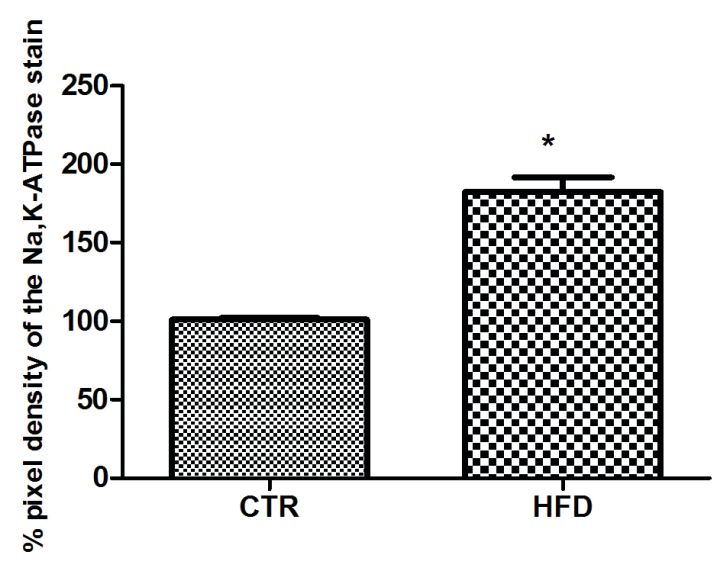

FIGURE 5 - Kidney Na,K-ATPase expression and location in mice treated with high fat diet. Immunohistochemistry of Na, K-ATPase alpha 1 subunit. A) Negative control 5x, B) Negative control 40x, C) Control group 5x, D) Control group 40x, E) HFD Group 5x, F) HFD Group 40x and G) Quantitative determination of labeled cells (total amount in 10 fields per experiment). H) Percentage of pixel density of the Na,K-ATPase staining.

by reducing leptin secretion in adipose tissue (Ainslie et al., 2000).

The immunohistochemistry analysis showed that amount of $\mathrm{Na}, \mathrm{K}$-ATPase positive cells were increased in the renal tubular region of the HFD group. In this context, Bickel et al. (2001) supported our results. They described that obese Zucker rats significantly increased the $\alpha 1$ subunit of Na,K-ATPase in the rat's kidneys, probably because of the predominance of the proximal tubules in the cortex. However, we found high $\mathrm{Na}, \mathrm{K}$-ATPase amounts in the kidney tubules and the Na,K-ATPase activities were significantly reduced in the HFD group but, the role of how this inhibition occurs is not clear.

Curiously, we found a difference in Na,K-ATPase activity between the right and left kidneys. There are papers demonstrated asymmetry of the kidneys, with a substantial differences between left and right renal blood flow may be present in up to $51 \%$ of hypertensive patients with angiographically proven patent renal arteries (van Onna et al., 2003). In an evaluation of a large group of hypertensive patients by renal scintigraphy, it was noticed that, without captopril challenge, the single kidney fractional uptake was statistically significantly lower on the left side than on the right side (46\% versus 54\%) (van Jaarsveld et al., 1997). Furthermore, some studies have already shown that there is a difference in levels and activity of $\mathrm{Na}, \mathrm{K}$-ATPase in right and left kidney and that they can be modulated differently (Kava et al., 

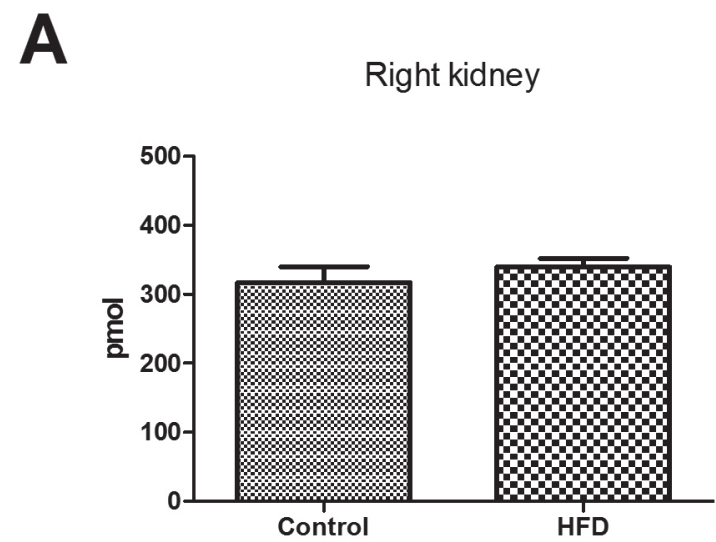

C

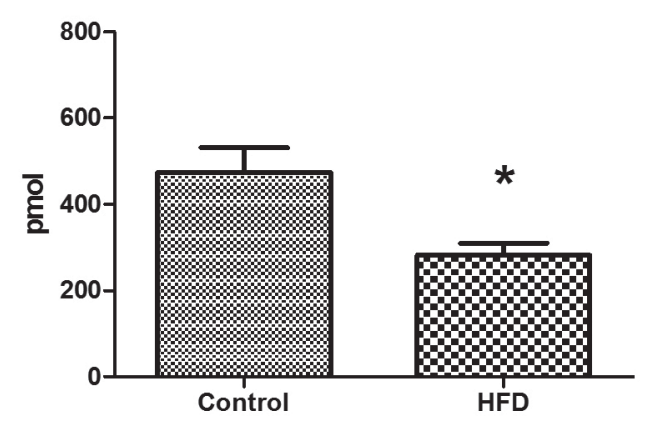

B

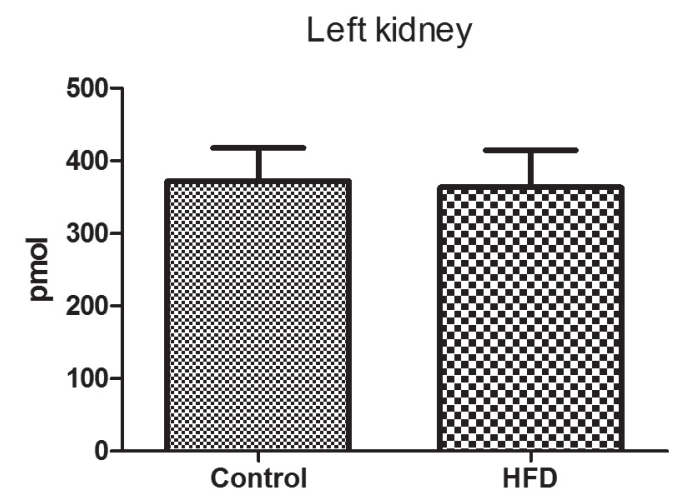

D

Left kidney

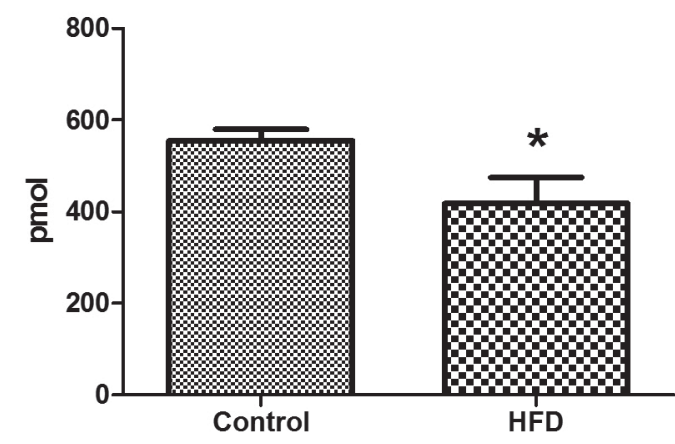

FIGURE 6 - Total lipid profile of kidney of mice fed with high fat diet. Total phospholipids (A, B) and cholesterol (C, D) were measured from kidney membrane preparation. The experiments were performed in triplicate. ${ }^{*}$ represent $\left.\mathrm{p}<0.05\right)$ of $t$ test $(\mathrm{n}=6)$.

2012; Yingst et al., 2009). Nevertheless, it is important to emphasize that the effect of HFD is the same for both kidneys and that the Na,K-ATPase can have different modulated in kidneys.

The reduction of cholesterol in the cell membrane increases its fluidity and makes the cell more sensitive to lipid peroxidation (Van der Paal et al., 2016). Obesity is associated with an increased on the generation of reactive oxygen species from the mononuclear cells. Oxidative injuries to the kidney stimulates the angiotensin synthesis by inducing the PKC and p38MAPK signaling systems (Chalmers, Kaskel, Bamgbola, 2006). Although no changes of lipid peroxidation were observed in the left kidney, it was increased about $25 \%$ in the right kidney of HFD group. This process is an important factor to the modulation of Na,K-ATPase activities, probably because modification on the membrane microenvironment is associated to changes on protein conformation which may reduce the pump activity (Rodrigo et al., 2007; Rodrigo et al., 2014).
Recent studies have been shown that a HFD can cause a reduction of the $\mathrm{Na}, \mathrm{K}-\mathrm{ATP}$ ase expression and this could also potentially impact the albumin uptake and the sodium reabsorption (Briffa et al., 2015). It has been demonstrated that $\mathrm{Na}, \mathrm{K}$-ATPase is located also in caveolae (Cai et al., 2008). There are several reports showing influence of cholesterol and phospholipids of the cell membranes on the activity of Na,K-ATPase (Cornelius, 2008; Rodrigo et al., 2014). The possible modulation of the Na,K-ATPase could be due to the modification of the lipid contents of the kidney cell membranes. It is further known that the $\mathrm{Na}, \mathrm{K}-\mathrm{ATPase}$ can serve as a cell membrane cholesterol level sensor and can directly connect to this particular molecule. Thus, Na,K-ATPase may regulate the cholesterol synthesis and the distribution of the cellular signaling pathways (Chen et al., 2009). In addition, the HFD regulates cholesterol metabolism, and $\mathrm{Na}, \mathrm{K}$-ATPase signaling pathway is involved in this process possibly by regulating the expression of lipid metabolism-associated proteins HMG-CoA reductase and SREBP-2 (Wang et al., 2015). 
A

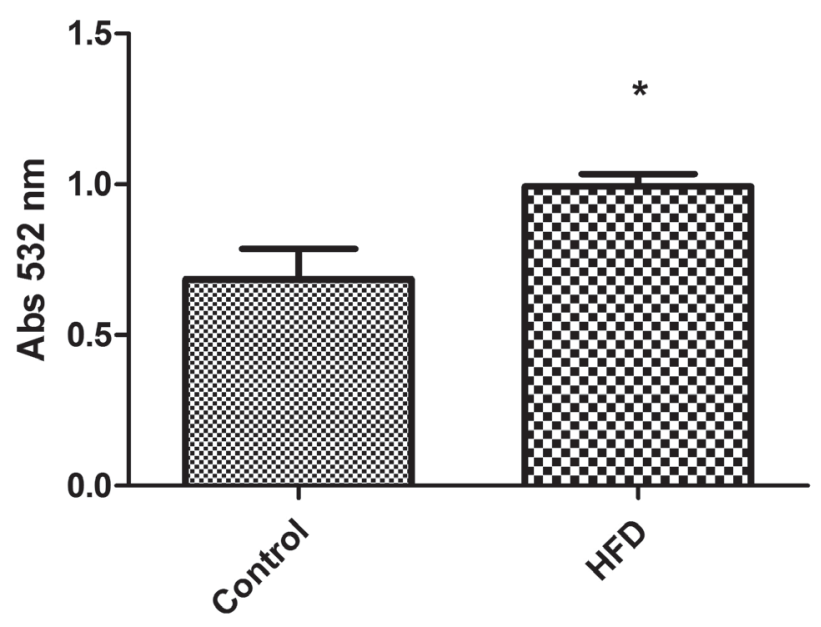

B

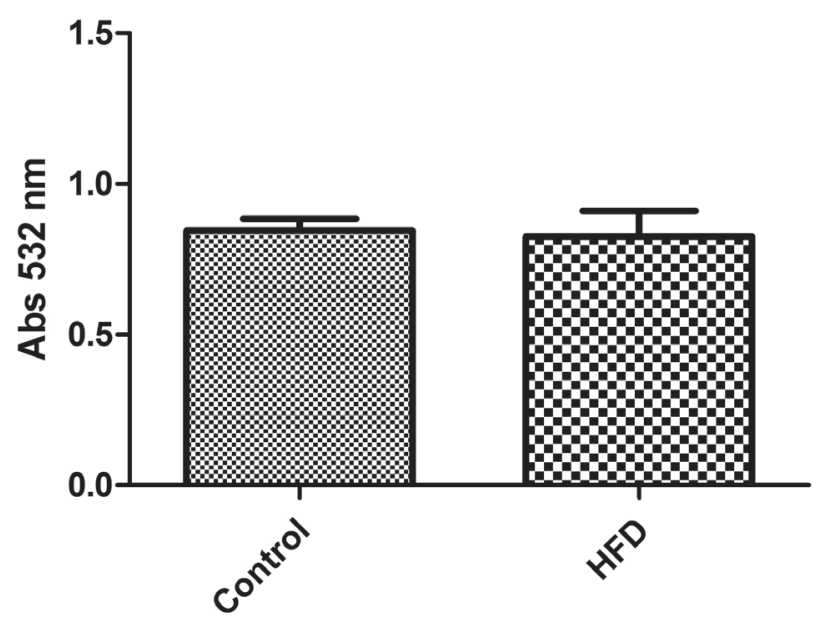

FIGURE 7 - Lipid peroxidation determination of kidney membrane preparation of HFD mice. Right (A) and left (B) kidney membrane preparations were used. The experiments were performed in triplicate. * Significant difference between the group under treatment and control group $(\mathrm{p}<0.05)$. $(\mathrm{n}=4)$.

Several studies have indicated that the lipid microenvironment affects the $\mathrm{Na}, \mathrm{K}$-ATPase activities. The Na,K-ATPase activities and structures are strongly modulated by a cholesterol presence in the membranes and changes in the amounts of that molecule can lead to increased or decreased activities (Cornelius, 2008; Cuevas, Jameson, Sotomayor, 2006). The addition of cholesterol to the membrane mimetic systems can also cause a destabilization of the phospholipid bilayer and these changes were recognized in the protein conformations (Yoneda et al., 2014). Another study investigating the effects of cholesterol on the $\mathrm{Na}, \mathrm{K}$ ATPase activities has shown that maximum enzyme activities can be observed in the presence of an specific amount of cholesterol in the membrane. When the levels of cholesterol are above or below to such amount, the pump activity decreases (Yeagle, Young, Rice, 1988). All together, this explains the observation of a significant reduction of cholesterol contents (Figure $6 \mathrm{C}, \mathrm{D}$ ) and $\mathrm{Na}, \mathrm{K}$-ATPase (Figure 4).

Leptin resistance induced by a HFD seems to involve different causes, mainly a defect in peripheral leptin ability in activate hypothalamus areas, and impaired intracellular signaling in leptin-responsive hypothalamic neurons (ElHaschimi et al., 2000). Several studies have demonstrated that there is an increment of leptin levels in obese subjects (Fine, Fine, 1997; Savino et al., 2013) and other studies have demonstrated that leptin induces a time- and dosedependent decrement in the Na,K-ATPase activities in the renal medulla (Beltowski, Marciniak, Wojcicka, 2004). In addition, leptin acts via activation of $\mathrm{p} 38 \mathrm{MAPK}$ and PKC. These two proteins can inhibit the Na,K-ATPase (El-Zein et al., 2015). Briffa et al. (2015) suggested that there was a direct relationship between the levels of leptin and the decreased expression levels of the kidney Na,K-ATPase, through a pathway involving the modulation of ERK1/2. In our model, the leptin levels remained unchanged. However, we did observe a remarkable increase in the insulin levels and insulin resistance. This is commonly associated with a decrement of the $\mathrm{Na}, \mathrm{K}$-ATPase activity (Galuska et al., 2009).

It has been described that insulin increases the sodium reabsorption in the proximal tubule (the thick ascending limb) and the distal tubule, including the collecting duct (Feraille et al., 1995; Ito et al., 1997). However, it has been shown that an insulin treatment has caused an internalization of the $\alpha 1$ isoform of $\mathrm{Na}, \mathrm{K}$ ATPase in LLC-PK1 cells. Those particular authors have suggested that the sodium pump and the insulin receptor compete for intracellular proteins (which are necessary for an endocytosis process) (Gupta et al., 2012). Therefore, a possible explanation for the decreased $\mathrm{Na}, \mathrm{K}$-ATPase activities may be due to the augment of circulating insulin, causing an internalization of the pump. This also may explain the decrease on the expression levels of the $\mathrm{Na}, \mathrm{K}$ ATPase enzyme observed in the kidneys during previous studies (Briffa et al., 2015).

Our investigation showed an effect of a HFD on kidney function. We observed that a diet rich in lipids induced the weight gain, altered the renal cellular morphology, without affect the blood levels of creatinine and urea. An important enzyme for renal function, Na,KATPase, has been shown to decrease its activity and increase its expression in the mouse kidneys in response to HFD. Interestingly, the HFD reduced the cholesterol 
content of the membrane within the kidney. Divergently from lipid peroxidation of the cell membrane. These changes in the membrane, and perhaps the internalization of Na,K-ATPase due to the elevated circulating levels of insulin, may have contributed to impair the $\mathrm{Na}, \mathrm{K}$-ATPase activity in mice treated with the high fat diet.

Therefore, our results suggest that a high fat diet may be a contributing factor to induce or accelerate the progression of renal disease which is a special concern pre-diabetes or diabetes population, or patients already diagnosed with renal injury.

\section{ACKNOWLEDGMENT}

This work was supported by FAPEMIG (Fundação de Amparo a Pesquisa do Estado de Minas Gerais) APQ00290-16, CAPES (Coordenação de Aperfeiçoamento de Pessoal de Nível Superior) and CNPq (Conselho Nacional de Desenvolvimento Científico e Tecnológico) 401914/2016-0.

\section{CONFLICTS OF INTEREST}

The authors declare that there is no conflict of interest.

\section{LIST OF ABBREVIATIONS:}

WHO - World Health Organization

HFD - High fat diets

NAFLD - Non-alcoholic fatty liver disease

HEPES - 4-(2-Hydroxyethyl)-1-piperazineethanesulfonic acid

CD36 - Fatty acid translocase

ATP - Adenosine triphosphate

PBS - Phosphate-buffered saline

BSA - Bovine serum albumin

HRP - Horseradish peroxidase

RET - Retroperitoneal

EPD - Epididimal

CKD- Chronic kidney disease

ROS - Reactive Oxygen Species

TBARS - Thiobarbituric acid reactive substances

PKC - Protein kinase $\mathrm{C}$

TNF- $\alpha$ - Tumor necrosis factor alpha

p38MAPK - P38 mitogen-activated protein kinases

$\mathrm{CD} 11 \mathrm{c}$ - Integrin alpha $\mathrm{X}$ chain protein

FFA - Serum free fatty acid

WAT - White adipose tissue

TAG - Triacylglycerol

\section{REFERENCES}

Ainslie DA, Proietto J, Fam BC, Thorburn AW. Short-term, high-fat diets lower circulating leptin concentrations in rats. Am J Clin Nutr. 2000;71(2):438-442.

Beltowski JGWj, Gorny D, Marciniak A. Human leptin administered intraperitoneally stimulates natriuresis and decreases renal medullary $\mathrm{Na}+, \mathrm{K}+$-ATPase activity in the rat - impaired effect in dietary-induced obesity. Med Sci Monit. 2002;8(6):21-229.

Beltowski J, Marciniak A, Wojcicka G. Leptin decreases renal medullary $\mathrm{Na}^{+}, \mathrm{K}+-$ ATPase activity through phosphatidylinositol 3-kinase dependent mechanism. J Physiol Pharmacol. 2004;55(2):391-407.

Bickel CA, Verbalis JG, Knepper MA, Ecelbarger CA. Increased renal Na-K-ATPase, NCC, and beta-ENaC abundance in obese Zucker rats. Am J Physiol Renal Physiol. 2001;281(4):F639648.

Briffa J F, Grinfeld E, Jenkin KA, Mathai ML, Poronnik P, McAinch AJ, et al. Diet induced obesity in rats reduces NHE3 and $\mathrm{Na}(+) / \mathrm{K}(+)$-ATPase expression in the kidney. Clin Exp Pharmacol Physiol. 2015;42(10):1118-1126.

Buege JA, Aust SD. Microsomal lipid peroxidation. Methods Enzymol. 1978;52:302-310.

Cai T, Wang H, Chen Y, Liu L, Gunning WT, Quintas LE, et al. Regulation of caveolin-1 membrane trafficking by the $\mathrm{Na} / \mathrm{K}$ ATPase. J Cell Biol. 2008;182(6):1153-1169.

Cao H, Gerhold K, Mayers JR, Wiest MM, Watkins SM, Hotamisligil GS. Identification of a lipokine, a lipid hormone linking adipose tissue to systemic metabolism. Cell. 2008;134(6):933-944.

Chalmers L, Kaskel FJ, Bamgbola O. The role of obesity and its bioclinical correlates in the progression of chronic kidney disease. Adv Chronic Kidney Dis. 2006;13(4):352-364.

Chauhan V, Vaid M. Dyslipidemia in chronic kidney disease: managing a high-risk combination. Postgrad Med. 2009;121(6):54-61.

Chen PS, Toribara TY, Warner H. Microdetermination of phosphorus. Anal Chem. 1956;28(11):1756-1758. 
Chen Y, Cai T, Wang H, Li Z, Loreaux E, Lingrel JB, et al. Regulation of intracellular cholesterol distribution by $\mathrm{Na} / \mathrm{K}$ ATPase. J Biol Chem. 2009;284(22):14881-14890.

Choudhury D, Tuncel M, Levi M. Disorders of lipid metabolism and chronic kidney disease in the elderly. Semin Nephrol. 2009;29(6):610-620.

Cornelius F. Cholesterol-dependent interaction of polyunsaturated phospholipids with Na,K-ATPase. Biochemistry. 2008;47(6):1652-1658.

Crescenzo R, Bianco F, Mazzoli A, Giacco A, Cancelliere R, di Fabio G, et al. Fat quality influences the obesogenic effect of high fat diets. Nutrients. 2015;7(11):9475-9491.

Cuevas FJ, Jameson DM, Sotomayor CP. Modulation of reconstituted pig kidney $\mathrm{Na}+/ \mathrm{K}+$-ATPase activity by cholesterol in endogenous lipid vesicles: Role of lipid domains. Biochemistry. 2006;45(46):13855-13868.

Dalboge LS, Pedersen PJ, Hansen G, Fabricius K, Hansen HB, Jelsing J, et al. A hamster model of diet-induced obesity for preclinical evaluation of anti-obesity, anti-diabetic and lipid modulating agents. PLoS One. 2015;10(8):e0135634.

El-Haschimi K, Pierroz DD, Hileman SM, Bjorbaek C, Flier JS. Two defects contribute to hypothalamic leptin resistance in mice with diet-induced obesity. J Clin Invest. 2000;105(12):18271832.

El-Zein O, Usta J, El Moussawi L, Kreydiyyeh SI. Leptin inhibits the $\mathrm{Na}(+) / \mathrm{K}(+)$ ATPase in Caco-2 cells via PKC and p38MAPK. Cell Signal. 2015;27(3):416-423.

Feraille E, Rousselot M, Rajerison R, Favre H. Effect of insulin on $\mathrm{Na}+, \mathrm{K}(+)$-ATPase in rat collecting duct. J Physiol. 1995;488(Pt 1):171-180.

Fine JB, Fine RM. Leptin levels in obesity. Int J Dermatol. 1997;36(10):727-728.

Folch J, Lees M, Stanley GHS. A simple method for the isolation and purification of total lipides from animal tissues. J Biol Chem. 1957;226(1):497-509.

Frazier-Wood AC. Dietary patterns, genes, and health: challenges and obstacles to be overcome. Curr Nutr Rep. 2015;4:82-87.
Galuska D, Kotova O, Barres R, Chibalina D, Benziane B, Chibalin AV. Altered expression and insulin-induced trafficking of $\mathrm{Na}+-\mathrm{K}+$-ATPase in rat skeletal muscle: effects of high-fat diet and exercise. Am J Physiol Endocrinol Metab. 2009;297(1):E3849.

Gupta S, Yan Y, Malhotra D, Liu J, Xie Z, Najjar SM, et al. Ouabain and insulin induce sodium pump endocytosis in renal epithelium. Hypertension. 2012;59(3):665-672.

Heinonen JK, Lahti RJ. A new and convenient colorimetric determination of inorganic orthophosphate and its application to the assay of inorganic pyrophosphatase. Anal Biochem. $1981 ; 113(2): 313-317$.

Henegar JR, Bigler SA, Henegar LK, Tyagi SC, Hall JE. Functional and structural changes in the kidney in the early stages of obesity. J Am Soc Nephrol. 2001;12(6):1211-1217.

Ito O, Kondo Y, Oba M, Takahashi N, Omata K, Abe K. Tyrosine kinase, phosphatidylinositol 3-kinase, and protein kinase $\mathrm{C}$ regulate insulin-stimulated $\mathrm{NaCl}$ absorption in the thick ascending limb. Kidney Int. 1997;51(4):1037-1041.

Kambham N, Markowitz GS, Valeri AM, Lin J, D’Agati VD. Obesity-related glomerulopathy: an emerging epidemic. Kidney Int. 2001;59(4):1498-1509.

Kava L, Rossi NF, Mattingly R, Yingst DR. Increased expression of $\mathrm{Na}, \mathrm{K}$-ATPase and a selective increase in phosphorylation at Ser-11 in the cortex of the 2-kidney, 1-clip hypertensive rat. Am J Hypertens. 2012;25(4):487-491.

Kennedy DJ, Chen Y, Huang W, Viterna J, Liu J, Westfall K, et al. CD36 and $\mathrm{Na} / \mathrm{K}$-ATPase-alpha1 form a proinflammatory signaling loop in kidney. Hypertension. 2013;61(1):216-224.

Kwon EY, Shin SK, Cho YY, Jung UJ, Kim E, Park T, et al. Time-course microarrays reveal early activation of the immune transcriptome and adipokine dysregulation leads to fibrosis in visceral adipose depots during diet-induced obesity. BMC Genomics. 2012;13:450.

Lee HS, Nam Y, Chung YH, Kim HR, Park ES, Chung SJ, et al. Beneficial effects of phosphatidylcholine on high-fat dietinduced obesity, hyperlipidemia and fatty liver in mice. Life Sci. 2014;118(1):7-14.

McKeown RE. The epidemiologic transition: changing patterns of mortality and population dynamics. Am J Lifestyle Med. 2009;3(1 Suppl):19S-26S. 
Rackova L. Cholesterol load of microglia: contribution of membrane architecture changes to neurotoxic power? Arch Biochem Biophys. 2013;537(1):91-103.

Reinhard L, Tidow H, Clausen MJ, Nissen P. Na(+), K $(+)$-ATPase as a docking station: protein-protein complexes of the $\mathrm{Na}(+), \mathrm{K}(+)$-ATPase. Cell Mol Life Sci. 2013;70(2):205222.

Rodrigo R, Bachler JP, Julia A, Prat H, Passalacqua W. Relationship between (Na plus K)-ATPase activity, lipid peroxidation and fatty acid profile in erythrocytes of hypertensive and normotensive subjects. Mol Cell Biochem. 2007;303(12):73-81.

Rodrigo R, Miranda-Merchak A, Grau RV, Bachler JP, Vergara L. Modulation of $(\mathrm{Na}, \mathrm{K})$-ATPase activity by membrane fatty acid composition: therapeutic implications in human hypertension. Clin Exp Hypert. 2014;36(1):17-26.

Sasatomi Y, Tada M, Uesugi N, Hisano S, Takebayashi S. Obesity associated with hypertension or hyperlipidemia accelerates renal damage. Pathobiology. 2001;69(2):113-118.

Savino F, Liguori SA, Benetti S, Sorrenti M, Fissore MF, Cordero di Montezemolo L. High serum leptin levels in infancy can potentially predict obesity in childhood, especially in formula-fed infants. Acta Paediatr. 2013;102(10):e455-459.

Seki G, Hideomi Y, Li Y, Horita S, Suzuki M, Toshiro F. The roles of abnormal renal sodium handling in hypertension associated with metabolic syndrome. Curr Hypert Rev. 2008;4(3):197-202.

Sharma R, Schumacher U, Ronaasen V, Coates M. Rat intestinal mucosal responses to a microbial flora and different diets. Gut. 1995;36(2):209-214.

Surwit RS, Petro AE, Parekh P, Collins S. Low plasma leptin in response to dietary fat in diabetes- and obesity-prone mice. Diabetes. 1997;46(9):1516-1520.

Szolkiewicz M, Sucajtys E, Chmielewski M, Wolyniec W, Rutkowski P, Boguslawski W, et al. Increased rate of cholesterologenesis - a possible cause of hypercholesterolemia in experimental chronic renal failure in rats. Horm Metab Res. 2002;34(5):234-237.
Van der Paal J, Neyts EC, Verlackt CCW, Bogaerts A. Effect of lipid peroxidation on membrane permeability of cancer and normal cells subjected to oxidative stress. Chem Sci. 2016;7(1):489-498.

van Jaarsveld BC, Krijnen P, Derkx FH, Oei HY, Postma CT, Schalekamp MA. The place of renal scintigraphy in the diagnosis of renal artery stenosis. Fifteen years of clinical experience. Arch Intern Med. 1997;157(11):1226-1234.

van Onna M, Houben AJ, Kroon AA, Wierema TK, Koster D, van Engelshoven JM, et al. Asymmetry of renal blood flow in patients with moderate to severe hypertension. Hypertension. 2003;41(1):108-113.

Wang L, Xu F, Zhang XJ, Jin RM, Li X. Effect of high-fat diet on cholesterol metabolism in rats and its association with $\mathrm{Na}(+) / \mathrm{K}$ (+)-ATPase/Src/pERK signaling pathway. J Huazhong Univ Sci Technolog Med Sci. 2015;35(4):490-494.

Yeagle PL, Young J, Rice D. Effects of cholesterol on $(\mathrm{Na}+, \mathrm{K}+)$-ATPase ATP hydrolyzing activity in bovine kidney. Biochemistry. 1988;27(17):6449-6452.

Yingst DR, Araghi A, Doci TM, Mattingly R, Beierwaltes WH. Decreased renal perfusion rapidly increases plasma membrane $\mathrm{Na}-\mathrm{K}-\mathrm{ATP}$ ase in rat cortex by an angiotensin II-dependent mechanism. Am J Physiol Renal Physiol. 2009;297(5):F13241329.

Yoneda JS, Rigos CF, de Lourenco TF, Sebinelli HG, Ciancaglini P. Na,K-ATPase reconstituted in ternary liposome: the presence of cholesterol affects protein activity and thermal stability. Arch Biochem Biophys. 2014;564:136-141.Issue number is missing

Young DO, Lund RJ, Haynatzki G, Dunlay RW. Prevalence of the metabolic syndrome in an incident dialysis population. Hemodial Int. 2007;11(1):86-95.

Received for publication on $05^{\text {th }}$ April 2017 Accepted for publication on $14^{\text {th }}$ August 2017 